\title{
Analysis of Risky Behavior towards Sexual Transmitted Infections (STIS) in the Community Health Center of Bintuni, West Papua
}

\author{
Panel Situmorang $^{1}$, Norma $^{1}$, Yogik Setia Anggraeni ${ }^{1}$, Anwar Mallongi ${ }^{2}$, Yahya $^{1}$ \\ ${ }^{1}$ Lecturers of Poltekkes Kemenkes Sorong, ${ }^{2}$ Professor of Environmental Health Department, \\ Faculty of Public Health, Hasanuddin University, Makassar
}

\begin{abstract}
The problem of STIs in Indonesia is believed to be like an iceberg phenomenon because the official report on the number of cases does not reflect the real problem. There is a high number of asymptomatic cases that the sufferer does not feel sick but can transmit the infection to other people. This study aims to analyze risky behavior towards STI incidents in the work area of the Community Health Center (Puskesmas) of Bintuni. This is analytic observation research, with a case-control design. A case-control study is carried out by identifying the case group and the control group, then retrospectively, the risk factors for STIs in the work area of the Community Health Center of Bintuniwere examined with a total of 102 respondents, each group of cases and a control group of 51 respondents. Data were analyzed using SPSS to test the Odd Ratio. Results: The analysis of knowledge resulted in the OR value of 2.771 , the analysis of attitude resulted in the OR value of 1.4644. Knowledge and attitude are risk factors for the incidence of STIs. This study suggests improving health education, especially about STIs, and the health office and health agencies should be more proactive in early detection of STI cases in the community.
\end{abstract}

Keywords: Knowledge, attitude, action, sexually transmitted infections.

\section{Introduction}

Sexually transmitted infections (STIs) are infections caused by bacteria, viruses, parasites, or fungi, which are transmitted primarily through sexual contact from an infected person to their sexual partners ${ }^{1}$. STIs are one of the top ten causes of unpleasant disease in young adult men and the second most common in young adult women in developing countries ${ }^{2}$.

According to the CDC in Upik et.al, the incidence of STIs out of 340 million new curable cases (syphilis, gonorrhea, chlamydial infections, and trichomonas infections) occurs annually in men and women aged 15- 49 years. Epidemiologically, the disease is spread throughout the world, with the highest incidence rates

\section{Corresponding Author:}

\section{Norma}

Lecturers of Poltekkes Kemenkes Sorong

e-mail:normepid@gmail.com recorded in South and Southeast Asia, followed by Saharan Africa, Latin America, and the Caribbean. In America, the number of women who suffer from chlamydial infections is 3 times higher than men. Of all women who suffer from chlamydial infections, the age group that makes the biggest contribution is those aged 15-24 years 3 .

The prevalence of STIs in developing countries is much higher than in developed countries. In pregnant women globally, the incidence of gonorrhea is 10-15 times higher, chlamydia infection is $2-3$ times higher, and syphilis is 10-100 times higher than the incidence of pregnant women in industrialized countries. Adolescents (15-24 years) are $25 \%$ of all sexually active populations but account for nearly $50 \%$ of all new STI cases acquired. The detected STI cases represent only $50 \%-80 \%$ of all STI cases in America. This reflects the limitations of screening and the lack of news coverage of IMS $^{2}$.

In Indonesia, based on the Integrated Biological and Behavioral Survey Report (IBBS) by the Indonesian 
Ministry of Health, the prevalence of STIs in 2013 showed that gonorrhea infection was $99.2 \%$, chlamydia was $125.1 \%$ and syphilis was $36.6 \%$. While the prevalence of HIV was $68,9 \%{ }^{4}$.

Everyone who is sexually active can contract an STI. But, there are several groups of people that have to be watched out for because they have a high risk of spreading the IMS, such as the people who like to keep changing their sexual partners and those who had only one sexual partner, but their sexual partners like to keep changing their sexual partners 5 .

The problem of STIs - HIV in Indonesia is believed to be like an iceberg phenomenon because the official report on the number of cases does not reflect the real problem. The number of asymptomatic cases so that the sufferer does not feel sick, but can transmit the disease to other people. The first step in overcoming this problem is that we must have supporting and accurate data. Many data on STIs - HIV has been found and various prevention efforts have been made. However, the trend of increasing the number of STI cases and finding new HIV cases continues to increase.

Based on the description of the background above, the researchers interested in conducting a study with the title "Analysis of Risky Behavior Towards Sexual Transmitted Infections (STIs) In The Community Health Center of Bintuni, West Papua”.

\section{Method}

This is analytic observational research, with a casecontrol design. Case-control is a study conducted by comparing two groups, namely the case group and the control group ${ }^{6}$.

The case population in this study were clients who had medical treatment and doctor diagnoses infected with sexually transmitted diseases (STIs) in the work area of the Bintuni Community Health Center as many as 82 clients and the control population in this study were clients who came to the health center for STIs test through laboratory examinations and were declared not infected by STIs. The sample size was 102 with a ratio between cases and controls 1: $1=51$ cases and 51 controls. The research was conducted in outpatient services and STI service units at the Bintuni Community Health Center ${ }^{7}$.

The number of STIs cases as the number of cases of Urethral Body Duh (DTU) from January to December 2016, was reposted as many as 10,672 cases and cases of genital ulcers/genital ulcers were reported as many as 1,628 cases. Cases of Sexually Transmitted Infection (STI) based on the syndrome and laboratory approach per risk group in 2016 for national Female Sex Workers/ FSW (89,792), Male Sex Workers/MSW (506), Transwomen $(6,951)$, Gay men $(39,681)$, Injected Drug Users/IDU (4,425), High Risk Couples/HRC (93,520), Sex Worker Customers/SWC (14,043), and Others $(192,786)$. For West Papua Province, the risk groups in 2016 were FSW $(1,301)$, MSW (-), trans-women (7), gay men (7), HRC (32), SWC (543) and others $(6,182)$ (SIHA MOH, 2016).

The number of pregnant women who visited the ANC for the first time and tested for syphilis at the national level was 43,873 people and 4,169 pregnant women who tested positive for syphilis and 1,254 pregnant women who were treated for syphilis were in West Papua. The number of pregnant women who first visited the ANC and were tested for syphilis was 1902, 120 people, and pregnant women who tested positive for syphilis and 60 people who were treated for syphilis. In one of the districts in West, Papua is TelukBintuni Regency, the number of STI cases in 2016 for the Bintuni Community Health Center was 94 cases and in 2017 from January to October there were 82 cases. Data on the latest HIV transmission pathways reported by the Directorate General of Disease Control and Environmental Health, Indonesian Ministry of Health, in the SIHA report per December 2016 according to risk factors is through heterosexual 17,754 cases, gay men 13,063 cases, others 5,479 cases and 12,479 unknown cases. The percentage of HIV infection reported by sex was male $63.3 \%$ and female $63.7 \%$, while the percentage of HIV infection reported by age was $\leq 4$ years $2.2 \%, 5-14$ years $1.0 \%, 15$ -19 years $3.7 \%, 20-24$ years $17.3 \%, 25-49$ years $69.3 \%$, $\geq 50$ years $6.5 \%{ }^{6}$. 


\section{Results}

\section{Univariate Analysis:}

Table 1. Respondent risk characteristics

\begin{tabular}{|c|c|c|c|c|c|c|}
\hline \multirow{3}{*}{ Characteristics } & \multicolumn{4}{|c|}{ Sexually Transmitted Infection Incidence } & \multirow{2}{*}{\multicolumn{2}{|c|}{ Amount }} \\
\hline & \multicolumn{2}{|c|}{ Case } & \multicolumn{2}{|c|}{ Control } & & \\
\hline & $\mathbf{n}$ & $\%$ & $\mathbf{n}$ & $\%$ & $\mathbf{n}$ & $\%$ \\
\hline \multicolumn{7}{|l|}{ Age } \\
\hline $15-24$ years & 17 & $33.3 \%$ & 20 & $39.2 \%$ & 37 & $36.3 \%$ \\
\hline $25-49$ Years & 34 & $66.7 \%$ & 29 & $56.9 \%$ & 63 & $61.8 \%$ \\
\hline 50- 59 years & 0 & 0 & 2 & $3.9 \%$ & 2 & $1.9 \%$ \\
\hline Amount & 51 & $100 \%$ & 51 & $100 \%$ & 102 & $100 \%$ \\
\hline \multicolumn{7}{|l|}{ Gender } \\
\hline Male & 2 & $3.9 \%$ & 2 & $3.9 \%$ & 4 & $3.9 \%$ \\
\hline Women & 49 & $96.1 \%$ & 49 & $96.1 \%$ & 98 & $96.1 \%$ \\
\hline Amount & 51 & $100 \%$ & 51 & $100 \%$ & 102 & $100 \%$ \\
\hline \multicolumn{7}{|l|}{ Education } \\
\hline Elementary & 7 & $13.8 \%$ & 8 & $15.7 \%$ & 15 & $14.7 \%$ \\
\hline Junior High & 22 & $43.1 \%$ & 15 & $29.4 \%$ & 37 & $36.3 \%$ \\
\hline High school & 22 & $43.1 \%$ & 24 & $47.1 \%$ & 46 & $45.1 \%$ \\
\hline Higher education & 0 & 0 & 4 & $7.8 \%$ & 4 & $3.9 \%$ \\
\hline Amount & 51 & $100 \%$ & 51 & $100 \%$ & 102 & $100 \%$ \\
\hline \multicolumn{7}{|l|}{ Marital Status } \\
\hline Single & 14 & $27.5 \%$ & 18 & $35.3 \%$ & 32 & $31.4 \%$ \\
\hline Married & 8 & $15.7 \%$ & 6 & $11.7 \%$ & 14 & $13.7 \%$ \\
\hline Widow & 29 & $56.8 \%$ & 25 & $49.0 \%$ & 54 & $52.9 \%$ \\
\hline Amount & 51 & $100 \%$ & 51 & $100 \%$ & 102 & $100 \%$ \\
\hline \multicolumn{7}{|l|}{ Profession } \\
\hline Civil servants & 0 & 0 & 1 & $2 \%$ & 1 & $1 \%$ \\
\hline Private employees & 1 & $2 \%$ & 0 & 0 & 1 & $1 \%$ \\
\hline Entrepreneur & 1 & $2 \%$ & 2 & $4 \%$ & 3 & $3 \%$ \\
\hline Housewife & 2 & $4 \%$ & 5 & $9.8 \%$ & 7 & $6.9 \%$ \\
\hline Sex worker & 47 & $92 \%$ & 39 & $76.4 \%$ & 88 & $86.2 \%$ \\
\hline Unemployed & 0 & 0 & 4 & $7.8 \%$ & 4 & $3.9 \%$ \\
\hline Amount & 51 & $100 \%$ & 51 & $100 \%$ & 102 & $100 \%$ \\
\hline
\end{tabular}

Based on table 1 above, it shows that most case groups were respondents aged 25-49 years, which was $66.7 \%$, while in the control group the most were respondents aged $25-49$ years, which was $56.9 \%$. In the respondents' gender cases and the control group had the same number of respondents, most respondents were females at 96,1\%. At the education level of the respondents, the case group at the junior and senior high school education level had the same high proportion, which was $43.1 \%$, while the control group had the highest proportion of respondents with high school education, which was $47.1 \%$. Based on marital status in the case group and the control group, the highest proportions were respondents with widow status, 58,8\%, and 49\% respectively. Most respondents in the case and control groups were female sex workers, $92 \%$ and $76.4 \%$, respectively. 
The analysis Bivariate risk behaviors to the incidence of Sexually Transmitted Infections

\section{a. Knowledge}

Table 2. Results of Knowledge Analysis of Events Sexually Transmitted Infections

\begin{tabular}{|c|c|c|c|c|c|c|c|}
\hline \multirow{3}{*}{ Variable } & \multicolumn{4}{|c|}{ Sexually Transmitted Infection Incidence } & \multirow{2}{*}{\multicolumn{2}{|c|}{ Amount }} & \multirow{3}{*}{ OR $(95 \% \mathrm{CI})$} \\
\hline & \multicolumn{2}{|c|}{ Case } & \multicolumn{2}{|c|}{ Control } & & & \\
\hline & $\mathbf{n}$ & $\%$ & $\mathbf{n}$ & $\%$ & $\mathbf{n}$ & $\%$ & \\
\hline Knowledge & & & & & & & \\
\hline Less & 19 & $37.3 \%$ & 9 & $17.6 \%$ & 28 & $27.5 \%$ & 2,111 \\
\hline Well & 32 & $62.7 \%$ & 42 & $82.4 \%$ & 74 & $72.5 \%$ & $(1)^{108-6031)}$ \\
\hline Amount & 51 & $100 \%$ & 51 & $100 \%$ & 102 & $100 \%$ & (1) \\
\hline
\end{tabular}

Based on Table 2 above, it shows that the comparison of proportions between cases and controls, respondents with less knowledge, higher in case group (37, $3 \%$ ) compared with the control group (17.6\%). The results of the odds ratio test show the value of $\mathrm{OR}=2.771 ; 95 \%$ $\mathrm{CI}=1.108-6,931$, which means that knowledge is a risk factor for the incidence of STIs.

\section{b. Attitude}

Table 3. The results of the analysis of attitudes towards the incidence of STIs

\begin{tabular}{|c|c|c|c|c|c|c|c|}
\hline \multirow{3}{*}{ Variable } & \multicolumn{4}{|c|}{ Sexually Transmitted Infection Incidence } & \multirow{2}{*}{\multicolumn{2}{|c|}{ Amount }} & \multirow{3}{*}{ OR $(95 \% \mathrm{CI})$} \\
\hline & \multicolumn{2}{|c|}{ Case } & \multicolumn{2}{|c|}{ Control } & & & \\
\hline & $\mathrm{n}$ & $\%$ & $\mathrm{n}$ & $\%$ & $\mathbf{n}$ & $\%$ & \\
\hline Attitude & & & & & & & \\
\hline Less & 7 & $13.7 \%$ & 5 & $9.8 \%$ & 12 & $27.5 \%$ & 1,464 \\
\hline Well & 44 & $86.3 \%$ & 46 & $90.2 \%$ & 90 & $72.5 \%$ & $(0.432-4,957)$ \\
\hline Amount & 51 & $100 \%$ & 51 & $100 \%$ & 102 & $100 \%$ & \\
\hline
\end{tabular}

Based on Table 3 above, shows that $13,7 \%$ of respondents in the case group had less attitude, higher compared to the control group by $9.8 \%$. Based on the results of the analysis, the $\mathrm{OR}=1.464$; CI 95\% $=0.432$ 4.957, which means that attitude is a risk factor for the incidence of sexually transmitted infections.

\section{Discussion}

Knowledge risk of the incidence of sexually transmitted infections: Based on the results it shows that the largest proportion of respondents in the control group good knowledge i.e 82,4 \% compared to the case group that was $62.7 \%$. While the largest proportion of respondents that has a lack of knowledge in the case group is $37,3 \%$ and $17.6 \%$ in the control group. The results of the analysis of odds ratio $\mathrm{OR}=2.771 ; 95 \%$ $\mathrm{CI}=1.108-6,931$, which means that knowledge is a risk factor for the incidence of sexually transmitted infections (STIs). One of the factors affecting knowledge is the level of education ${ }^{8}$. The higher a person's education, the better the knowledge about the risk of sexually transmitted infections, and vice versa. Table 1, shows that only $3.9 \%$ of respondents were highly educated so that knowledge about the risk of sexually transmitted infections was lacking which had an impact on the risk of exposure.

The results of this study are not in line with the results of research by Masni (2016), concerning risk factors for sexually transmitted infections at the Kalumata Health Center, Ternate City ${ }^{9}$ which shows that knowledge is not a risk factor for the incidence of sexually transmitted infections, because knowledge has a major contribution in changing one's behavior to behave both positively and negatively. Sufficient knowledge about sexually 
transmitted diseases encourages a person to be more aware of diseases that can be transmitted through sexual activity $^{10}$.

The results of this study are also in line with the results of Ristiani's ${ }^{11}$ research on the relationship between the level of knowledge about infectious infections and premarital sex attitudes in $8^{\text {th }}$-grade students at Muhammadiyah 9 Junior High School, Yogyakarta, which states that there is a significant relationship about the level of knowledge about sexually transmitted infections with premarital sex attitudes in $8^{\text {th }}$-grade students

Anyone that sexually active is at risk of contracting an STI. Factors that increase the risk include having sex without a condom, having sex with a changing partner, the behavior of a high-risk sexual partner, and having a history of STIs ${ }^{12}$.

Risk Factors Attitudes towards the incidence of sexually transmitted infections: The results showed that $13,7 \%$ in the case group had a poor attitude was higher than $9.8 \%$ in the control group with the test results show the value of the odds ratio OR $=1,464 ;$ CI95\% $=$ $0.432-4,957$ which means that attitude is a risk factor for the incidence of sexually transmitted infections.

According to Gerungan ${ }^{13}$, an attitude is a person's opinion or view of an object that precedes his action. Attitudes may not be formed before receiving information, seeing, or experiencing an object. Adult age can form a person's opinion or a wider viewpoint about an object. There are $61 \%$ of respondents who are adults but do not make a positive contribution to healthy behavior.

The results of this study are not consistent with the results of research by Gani ${ }^{14}$ about the relationship of knowledge, attitudes, and behavior towards the incidents of Sexually Transmitted Infections in housewives at Bukittinggi, West Sumatra province that showed attitude is not a risk factor for the incidence of sexually transmitted infections $(\mathrm{OR}=0.99)$.

Attitudes often reflect a person's personality because they are inseparable from the person who supports them. Therefore, by looking at the attitude of a certain object, more or fewer people can know that person's personality. So attitude is a personal statement ${ }^{15-23}$.

In general, respondents have a good attitude in preventing sexually transmitted infections, including the statement that using condoms is a safe way to prevent STI transmission, having more than 1 sexual partner can be at risk of contracting STIs, anal sex is very risky of contracting STIs, sucking or putting genitals into the mouth (Oral sex) can be very risky of contracting STIs, however, a person's attitude can change due to the state of the human being that moves to act or act in social activities with certain feelings in response to the object of the situation or conditions in the surrounding environment ${ }^{6}$.

Acknowledgment: Thank you to the Head of the Bintuni Community Health Center who has permitted the researchers to conduct this research.

Ethical Clearance: Taken from Poltekkes Kemenkes Sorongethical committee

Source of Funding: Poltekkes Kemenkes Sorong

\section{Conflict of Interest: Nil}

\section{Reference}

1. S. Maposa, A.J. Afolayan, and G.A. Otunola, Evaluation of the Antimicrobial Properties of Vachelliakarroo Hayne Banfi and Galasso Pods Used Traditionally for the Treatment of Venereal Diseases. International Journal of Pharmacology, 2019; 15: 772-776. DOI: 10.3923/ ijp.2019.772.776. URL: https://scialert.net/ abstract/?doi=ijp.2019.772.776.

2. Sarwono, Quantitative and Qualitative Research Method, Graha Ilmu. 2008.,

3. Upik R Upik, K Gustinidan Puspita APW. Class XI Students' Knowledge of Sexually Transmitted Diseases. Indonesian Journal of Nursing Education 1(2): 105-115. URL :http://ejournal.upi.edu/index. php/JPKI.

4. SIHA Kemenkes. Integrated Survey of Biological and Behavioral. Siha.kemenkes.go.id. Retrieved January 2019.

5. Norma, Rumangun, Daud. Pengaruh Pendidikan KesehatanTentang Safe Sex Terhadap Perilaku Sex Sehat Pada Laki-Laki Homoseksual (Gay) Di Kota Sorong. Jurnal Nursing Arts, 2017; Vol 11 No 2. DOI: https://doi.org/10.36741/jna.v11i2.40. URL: https://poltekkes-sorong.e-journal.id/nursingarts/ article/view/PDf.

6. Notoatmodjo, S., Metodologi Penelitian Kesehatan, Rineka Cipta, Jakarta. 2010, 
7. Lemeshow, Stanlay. H. Jr David W, K. Janelle dan L. StphenK . Large Samples In Health Research. GadjaMada University Press, Yogyakarta. 2017.

8. Notoatmodjo, S., Health and Behavioral Health Promotion, Rineka Cipta, Jakarta. 2012,

9. Mappijanci, Masni. Risk Factors for The Incidence of Sexually Transmitted Infections in Puskesmas Kalumata Ternate City. Indonesian Public Health Media Hasanuddin University. URL :https://www. neliti.com/id/publications/212721/faktor-risikokejadian-infeksi-menular-seksual-di-puskesmaskalumata-kota-ternat.

10. Azwar, Asrul. Pengantar Administrasi Kesehatan. BinaraupaAksara, Jakarta.2010.

11. Ristiani, Aprilianaand Kurniawati, Herlin Fitriana. Knowledge Level relationship about sexually transmitted infections with prenuptial sex attitudes in Grade VIII students at SMP Muhammadiyah 9 Yogyakarta. Article, STIKES 'Aisyiyah Yogyakarta. 2014.

12. Norma, Rumangun, Daud. Deskripsi Perilaku Safe Sex Laki-LakiHomoseksual (Gay) di Kota Sorong. Jurnal Nursing Arts, 2017; Vol 11 No 1. DOI: https://doi.org/10.36741/jna.v11i1.38. URL : https://poltekkes-sorong.e-journal.id/nursingarts/ article/view/38.

13. A, Gerungan W. Psikologi Sosial. Bandung: Refikaaditama. 2002.

14. YulitaGani, Hubungan Pengetahuan, Sikap, dan Perilaku Terhadap Kejadian IMS Pada Ibu Rumah Tangga Di Kota Bukittinggi Provinsi Sumatera Barat Tahun 2013, Jurnal, FKM UI, Jakarta. 2013.

15. Comninos NB, Garton L, Guy R, et al Increases in pharyngeal Neisseria gonorrhoeae positivity in men who have sex with men, 2011-2015: observational study Sexually Transmitted Infections 2020;96:432435.

16. D Krau Stephen, J Pi TTChoUR Tney. Sexually Transmitted Infections, An Issue of Nursing Clinics, 2020; Volume 55-3 1st Edition. eBook ISBN: 9780323754552. URL: https://www.elsevier.com/ books/sexually-transmitted-infections-an-issue-ofnursing-clinics/pitts/978-0-323-75454-5.

17. Mallongi, A., Parkpian, P., Pataranawat, P., Chinwetkitvanich, S., Mercury distribution and its potential environmental and health risks in aquatic habitat at artisanal buladu gold mine in Gorontalo Province, Indonesia, Pakistan Journal of Nutrition Volume 14, Issue 12, 2015, Pages 1010-1025

18. A Mallongi, D Safiu, H Amqaim, A Syam, M Hatta, $\mathrm{T}$ Sutarti, A Muhith,.Modelling of S02 and CO Pollution Due to Industry PLTD Emission Tello in Makassar Indonesia. Journal of Engineering and Applied Sciences 14 (2), 634-640

19. Mallongi, A., Daud, A., Ishak, H., La Ane, R., Birawida, A.B., Ibrahim, E., Selomo, M., Rahman, S.A. Clean water treatment technology with an upflow slow sand filtration system from a well water source in the tallo district of Makassar. Journal of Environmental Science and Technology, 2017; Volume 10, Issue 1, Pages 44-48

20. Hasmi, Mallongi, A. Health risk analysis of lead exposure from fish consumption among communities along Youtefa Gulf, Jayapura. Pakistan Journal of Nutrition 2016; Volume 15, Issue 10, 15 September Pages 929-935

21. Kayame, R., Mallongi, A. Relationships between smoking habits and the hypertension occurrence among the adults of communities in paniai regency, Papua Indonesia. Indian Journal of Public Health Research and Development 2018; Volume 9, Issue 1, Pages 332-336

22. EndahYani, R.W., Mallongi, A., Andarini, S., Prijatmoko, D., Dewanti, I.R. The effect of zinc saliva on the toddlers' nutritional status. Journal of International Dental and Medical Research, 2016, Volume 9, Issue 1, Pages 29-32

23. Birawida, A.B., Selomo, M., Mallongi, A. Potential hazards from hygiene, sanitation and bacterium of refill drinking water at BarrangLompo island (water and food safety perspective) IOP Conference Series: Earth and Environmental Science 2018; Volume 157, Issue 1, Article number 012034 